Diabetologia 6, 425-429 (1970)

\title{
Abnormal Glucose Tolerance in Favism
}

\author{
A.G. Bulis, E.D. Xefteris, P.J. Ioannidens and S.C. Papastamatis \\ Department of Medicine, Athens University Medical School, King Paul Hospital, Athens, Greece
}

Received: October 1, 1969

Summary. Oral and intravenous glucose tolerance tests were carried out in 14 G6PD-deficient adult Greek patients, presenting with favism, and in 14 control subjects. Abnormal responses to either or both tests were obtained in 9 patients or 64.3 per cent, compared with none in the controls. Most of the abnormal results were seen among the older patients; age, however, did not seem to account for them. The possible significance of decreased carbohydrate tolerance in G6PD-deficiency is discussed.

Tolérance anormale au glucose dans le favisme

Résumé. Des tests de tolérance au glucose oral et intraveineux ont été effectués chez 14 sujets grecs ayant une déficience en glucose-6-phosphate déshydrogénase et atteints de favisme, ainsi que chez 14 sujets témoins.

Des réponses anormales soit à l'un, soit aux deux tests ont été obtenues chez neuf patients, soit $64.3 \%$ en comparaison avec les témoins chez lesquels aucune réponse n'était anormale. La plupart des résultats anormaux étaient observés chez les patients plus âgés; cependant, l'âge ne semblait pas expliquer ces résultats.
On discute de la signification possible de la tolérance diminuée aux hydrates de carbone dans la déficience en glucose-6-phosphate déshydrogénase.

\section{Störung der Glucosetoleranz bei Favismus}

Zusammenfassung. Bei 14 erwachsenen griechischen Patienten mit G6PD Mangel und den Symptomen eines Favismus und bei 14 stoffwechselgesunden Vergleichspersonen wurden orale und i.v. Glucosetoleranztests durchgeführt. Bei neun, bzw. $64.3 \%$ der Patienten, hingegen bei keiner der Kontrollpersonen fielen einer oder beide Tests pathologisch aus. Der größte Teil der anormalen Ergebnisse fand sich bei den älteren Patienten, doch schien das Lebensalter selbst nicht den entscheidenden Grund darzustellen. Die Frage der Bedeutung einer herab. gesetzten Glucosetoleranz bei G6PD-Mangel wird diskutiert.

Key-uords: Favism, abnormal glucose tolerance, G6PD-deficiency.
Glucose-6-phosphate dehydrogenase (G6PD) deficiency has been reported by Chanmugam and Frumin (1964) to be associated in adult Negroes with abnormal oral glucose tolerance tests. Their findings were not, however, confirmed by Eppes et al. (1966). The latter authors investigated the carbohydrate metabolism in G6PD-deficient adult Negro males, also by means of oral glucose tolerance tests; in some of their subjects they carried out, in addition, cortisone-modified glucose tolerance tests and tolbutamide tolerance tests.

Chanmugam and Frumin's report, along with our observation that elevated fasting blood sugars and transient glycosuria occur in some cases of favism, led us to the investigation of carbohydrate metabolism in this disorder. For this purpose, oral and intravenous glucose tolerance tests were done in G6PD-deficient Greek patients, presenting with acute haemolytic jaundice due to ingestion of fava beans.

\section{Materials and Methods}

Material: Consisted of 14 patients and 14 control subjects, all Greeks of Caucasian origin.

The patients, 9 males and 5 females, were studied between March 1966 and May 1968. Their age ranged from 15 to 64 years (mean age : 34.0 years). They were all admitted to King Paul Hospital with acute haemolytic jaundice following ingestion of fava beans. One patient (Table 1a, No. 6) gave a history of three haemolytic episodes in the past following the ingestion of analgesic and anti-inflammatory compounds, containing acetylsalicylic acid. In all cases, the haemolytic episodes occurred in the spring months of the years 1966,1967 and 1968 , and were of moderate to severe degree. The blood sugar and haematocrit values obtained on admission and subsequently in the course of their illness, as well as the highest bilirubin values attained, are shown in Table 1a. None of the patients was known to be diabetic or to have a family history of diabetes mellitus; however, 7 of them had, on admission, blood sugar values above $120 \mathrm{mg}$ per $100 \mathrm{ml}$ (No. 2, 3, 4, 5, 6, 10, 11). In two of those patients, No. 2 and 3 , the initial blood sugar was found to be $316 \mathrm{mg}$ and $290 \mathrm{mg}$ per $100 \mathrm{ml}$ respectively. They both presented with thirst, signs of dehydration and gross glycosuria, but they did not show any evidence of ketosis.

The control group consisted also of 9 males and 5 females, studied over the same period of time (Table $1 \mathrm{~b}$ ). Their age ranged from 24 to 66 years (mean age: 37.7 years). Five of them were apparently healthy medical students and young doctors with no family history of diabetes mellitus; the remainder were selected among patients being treated in the hospital for conditions which seem not to affect carbohydrate tolerance (Silverstone et al., 1956; Crockford et al., 1966).

None of the patients or the controls weighed more than $81 \mathrm{~kg}(180 \mathrm{lbs})$. 
Methods: Carbohydrate metabolism was investigated by the standard oral glucose tolerance test (oral G.T.T.) and the intravenous glucose tolerance test (intravenous G.T.T.). In 12 patients, the tests were done 7 to 38 days after the haemolytic episode (average interval time : for the oral G.T.T. 16 days, for the intravenous G.T.T. 18 days) within a 3 to 7 days' period from each other. In the other two patients (Table 1a, No. 6 and 9), the tests were done 8 to 10 weeks after two-and-a-half hours. For interpretation of the results, the criteria put forward by Mosenthal and Barry (1950) were used. Thus, curves were considered as normal, if peak and two-hour blood sugar values were less than 150 and $100 \mathrm{mg}$ per $100 \mathrm{ml}$, respectively; and as abnormal, when both these limits were exceeded.

Intravenous G.T.T. The commonly employed technique was used (Amatuzio et al., 1953; Silverstone et al., 1956). After obtaining a fasting blood specimen, $71 \mathrm{ml}$

Table 1a. Patient-group. Subject characteristics and laboratory data

\begin{tabular}{|c|c|c|c|c|c|c|c|c|c|c|}
\hline \multirow[t]{2}{*}{ No. } & \multirow[t]{2}{*}{ Patient } & \multirow[t]{2}{*}{ Sex } & \multirow[t]{2}{*}{ Age } & \multicolumn{3}{|c|}{$\begin{array}{l}\text { Serum bilirubin, mg } \\
\text { per } 100 \mathrm{ml}\end{array}$} & \multicolumn{2}{|c|}{$\begin{array}{l}\text { Blood sugar, } \mathrm{mg} \\
\text { per } 100 \mathrm{ml}\end{array}$} & \multicolumn{2}{|c|}{ Haematocrit } \\
\hline & & & & $\begin{array}{l}\text { Uncon } \\
\text { gated }\end{array}$ & $\begin{array}{l}\text { Conju- } \\
\text { gated }\end{array}$ & Total & $\begin{array}{l}\text { On } \\
\text { Admiss. }\end{array}$ & $\begin{array}{l}\text { On } \\
\text { Dis- } \\
\text { charge }\end{array}$ & Initial & Lowest \\
\hline 1 & A.K. & $F$ & 15 & 11.00 & 0.74 & 11.74 & 97 & 84 & 28 & 28 \\
\hline 2 & A.S. & $\mathbf{M}$ & 50 & 6.36 & 1.18 & 7.54 & 316 & 97 & 35 & 22 \\
\hline 3 & G.A. & $\bar{M}$ & 47 & 1.63 & 0.74 & 2.37 & 290 & 96 & 20 & 20 \\
\hline 4 & E.P. & $\mathrm{F}$ & 53 & 2.61 & 0.74 & 3.35 & 148 & 80 & 17.5 & 17.5 \\
\hline 5 & C.E. & $\mathbf{M}$ & 25 & 3.00 & 0.50 & 3.50 & 144 & 80 & 30 & 28 \\
\hline 6 & P.X.a & $\mathrm{F}$ & 26 & 6.92 & 0.83 & 7.75 & 132 & 90 & 31 & 31 \\
\hline 7 & T.A. & $\mathrm{M}$ & 16 & 7.52 & 0.83 & 8.35 & 95 & 75 & 24 & 24 \\
\hline 8 & C.K. & M & 17 & 5.39 & 0.90 & 6.29 & 93 & 81 & $\mathbf{3 4}$ & 29 \\
\hline 9 & B.S. & $\mathbf{M}$ & 29 & 3.67 & 0.56 & 4.23 & 91 & 85 & 34 & 34 \\
\hline 10 & J.K. & $\mathbf{M}$ & 64 & 2.02 & 0.93 & 2.95 & 168 & 84 & 24 & 24 \\
\hline 11 & T.S. & $\mathbf{M}$ & 47 & 6.05 & 1.20 & 7.25 & 124 & 90 & 30 & 30 \\
\hline 12 & M.T. & M & 17 & 5.00 & 0.70 & 5.70 & 88 & 82 & 35 & 32 \\
\hline 13 & $\mathrm{~K} . \mathrm{T}$. & $F$ & 45 & 1.58 & 0.45 & 2.03 & 117 & 102 & 25 & 25 \\
\hline 14 & A.L. & $\mathrm{F}$ & 26 & 1.63 & 0.55 & 2.18 & 93 & 99 & 33 & 33 \\
\hline
\end{tabular}

a Kernicterus in infancy. Drug sensitivity. Several haemolytic episodes in past.

Table 1b. Control group. Subject characteristics

\begin{tabular}{|c|c|c|c|c|}
\hline No. & $\begin{array}{l}\text { Pa- } \\
\text { tient }\end{array}$ & Sex & Age & Remarks \\
\hline 15 & B.D. & $\mathbf{F}$ & 26 & Anxiety neurosis \\
\hline 16 & G.K. & $\mathrm{M}$ & 45 & "Irritable colon" \\
\hline 17 & E.H. & M & 49 & $\begin{array}{l}\text { Lumbago, no organic lesion } \\
\text { found }\end{array}$ \\
\hline 18 & M.Z. & $\mathbf{F}$ & $\mathbf{3 7}$ & $\begin{array}{l}\text { Symptomless choledocholi- } \\
\text { thiasis }\end{array}$ \\
\hline 19 & N.M. & M & 24 & Multiple sclerosis \\
\hline 20 & E.X. & $\mathrm{F}$ & 35 & Healthy \\
\hline 21 & S.H. & $\mathrm{M}$ & 33 & Healthy \\
\hline 22 & P.P. & M & 28 & Healthy \\
\hline 23 & C.N. & $\mathrm{M}$ & 28 & Healthy \\
\hline 24 & C.S. & $\mathrm{M}$ & 24 & Healthy \\
\hline 25 & C.P. & M & 40 & Anxiety neurosis \\
\hline 26 & M.S. & $\mathrm{F}$ & 41 & Inactive duodenal ulcer \\
\hline 27 & L.F. & $\mathbf{M}$ & 66 & Prostatic hypertrophy \\
\hline 28 & A.B. & F & 52 & Symptomless haematuria \\
\hline
\end{tabular}

the haemolytic episode. A standard diet containing $250 \mathrm{~g}$ or more of carbohydrate and approximately 2000 calories was prescribed for at least 3 days prior to each test. The tests were done in the morning after a 12-h fast. Venous blood samples were used, and the blood sugar estimation was done on the same day by the Hagedorn-Jensen method. The details of each test are as follows:

Oral G.T.T. After drawing a fasting blood sample, $50 \mathrm{~g}$ of glucose was given and blood specimens were subsequently taken at one, one-and-a-half, two and of 35 per cent glucose solution, containing $25 \mathrm{~g}$ of glucose, was given intravenously within $2-4 \mathrm{~min}$. Serial venous blood samples were then drawn at 8-min intervals for $72 \mathrm{~min}$ (9 samples). The blood sugar values were plotted on the ordinate of a semi-logarithmic graph paper against time on the abscissa, and the rate of glucose utilization ( $K$-value) was calculated by the standard formula: $K=\frac{\log .2}{t 1 / 2} \times 100$, where $K$ is the rate of utilization of glucose per cent per min., and $t^{1 / 2}$ is the time in minutes, taken for the blood sugar concentration to reach half of the value at zero time.

In the interpretation of the results, $K$-values less than 1.00 were considered as abnormal and suggestive of decreased carbohydrate tolerance, according to several authors' experience (Amatuzio et al., 1953; Duncan, 1956; Lundbaek, 1962).

$G 6 P D$ activity. The enzyme activity was determined by the brilliant-cresyl-blue reduction test, designed by Motulski et al. (1959). A decolorization time of less than 60 min was considered to represent normal G6PD activity, and a time over $180 \mathrm{~min}$ as showing complete absence of enzyme activity; times between 60 and $180 \mathrm{~min}$ were interpreted as indicative of partial enzymatic activity.

All determinations of G6PD activity in the patient-group were done twice; that is, on their admission to the hospital, before any transfusion was given, and one month after the haemolytic episode. 


\section{Results}

The results are shown in Tables 2 and 3.

Oral G.T.T. Normal curves were obtained in all the control subjects. In the group of patients, abnormal curves were found in 8 cases, 4 males and 4 females (Table 2, No. 2, 3, 4, 5, 6, 10, 13, 14). Most of them were middle-aged individuals with a mean age of $42.0 \pm 5.2$ years; the mean age of the other six, who showed normal responses, was $23.5 \pm 3.8$ years. The difference in age was statistically significant at $P=0.01$.

A composite curve of the results of the test for both groups is shown in Fig. 1.

Intravenous G.T.T. Normal $K$-values, varying from 1.24 to 3.65 (mean : $1.88 \pm 0.19$ ) were found in all the control subjects. Abnormal $K$-values were obtained in 6 of the 14 patients (Table 2, No. 2, 3, 5, 6, 10, 11).

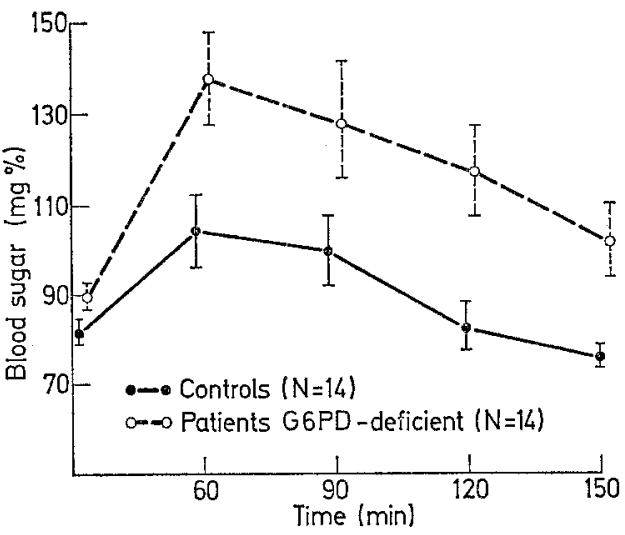

Fig. 1. Standard oral glucose tolerance tests. Mean values \pm standard error of the mean

Table 2. Results of the G6PD-activity and of the glucose tolerance tests for the patientgroup (Nos. 1-14) and the control group (Nos. 15-28)

\begin{tabular}{|c|c|c|c|c|c|c|c|c|c|}
\hline \multirow{2}{*}{ No. } & \multirow{2}{*}{ Sex } & \multirow{2}{*}{ Age } & \multirow{2}{*}{$\begin{array}{l}\text { G6PD } \\
\text { activity }\end{array}$} & \multicolumn{5}{|c|}{$\begin{array}{l}\text { Oral glucose tolerance test } \\
\text { (Blood sugar, mg per } 100 \mathrm{ml} \text { ) }\end{array}$} & \multirow{2}{*}{$\begin{array}{l}\text { Intravenous glu- } \\
\text { cose tolerance test } \\
\text { ( } K \text { Values, per } \\
\text { cent per min) }\end{array}$} \\
\hline & & & & Fast & $1 \mathrm{~h}$ & $11 / 2 \mathrm{~h}$ & $2 h$ & $21 / 2 \mathrm{~h}$ & \\
\hline 1 & $\mathrm{~F}$ & 15 & Absent & 88 & 106 & 92 & 88 & 79 & 1.30 \\
\hline 2 & $\mathbf{M}$ & 50 & Absent & 97 & 188 & - & 181 & 124 & 0.83 \\
\hline 3 & $\mathbf{M}$ & 47 & Absent & 96 & 148 & 154 & 157 & 150 & 0.98 \\
\hline 4 & $\mathrm{~F}$ & 53 & Decreased & 84 & 150 & 164 & 106 & 87 & 1.77 \\
\hline 5 & $\mathbf{M}$ & 25 & Absent & 97 & 172 & 188 & 165 & 133 & 0.87 \\
\hline 6 & $\mathrm{~F}$ & 26 & Absent & 97 & 197 & 208 & 164 & 138 & 0.70 \\
\hline 7 & $\mathbf{M}$ & 16 & Absent & 75 & 86 & 79 & 75 & 74 & 2.77 \\
\hline 8 & $\mathrm{M}$ & 17 & Absent & 83 & 79 & 75 & 75 & 72 & 1.06 \\
\hline 9 & $\mathbf{M}$ & 29 & Decreased & 70 & 99 & 77 & 92 & - & 1.22 \\
\hline 10 & $\mathrm{M}$ & 64 & Decreased & 99 & 156 & 146 & 145 & 108 & 0.83 \\
\hline 11 & $\mathrm{M}$ & 47 & Decreased & 90 & 155 & 111 & 74 & 68 & 0.94 \\
\hline 12 & $\mathrm{M}$ & 17 & Absent & 80 & 120 & 75 & 90 & 90 & 1.54 \\
\hline 13 & $\mathrm{~F}$ & 45 & Decreased & 100 & 131 & 167 & 124 & 105 & 1.57 \\
\hline 14 & $\mathbf{F}$ & 26 & Decreased & 104 & 159 & 135 & 117 & 104 & 1.12 \\
\hline$\overline{15}$ & $F$ & 26 & Normal & 70 & 100 & 170 & 60 & - & 2.48 \\
\hline 16 & $\mathbf{M}$ & 45 & Normal & 72 & 101 & 97 & 68 & 79 & 1.65 \\
\hline 17 & $\bar{M}$ & 49 & Normal & 76 & 113 & 93 & 74 & 63 & 1.36 \\
\hline 18 & $\mathrm{~F}$ & 37 & Normal & 73 & 125 & 113 & 108 & 84 & 1.24 \\
\hline 19 & $\mathbf{M}$ & 24 & Normal & 84 & 61 & 79 & 57 & 70 & 1.98 \\
\hline 20 & $\mathbf{F}$ & 35 & Normal & 79 & 70 & 88 & 56 & 65 & 2.66 \\
\hline 21 & $\mathbf{M}$ & 33 & Normal & 97 & 81 & 77 & 92 & 99 & 1.42 \\
\hline 22 & $\mathrm{M}$ & 28 & Normal & 90 & 97 & 79 & 84 & 88 & 3.65 \\
\hline 23 & M & 28 & Normal & 99 & 122 & 106 & 97 & 70 & 1.73 \\
\hline 24 & $\mathbf{M}$ & 24 & Normal & 88 & 64 & 88 & 106 & 66 & 2.56 \\
\hline 25 & M & 40 & Normal & 75 & 154 & 117 & 96 & 82 & 1.26 \\
\hline 26 & $\mathrm{~F}$ & 41 & Normal & 88 & 122 & 108 & 92 & 84 & 1.41 \\
\hline 27 & M & 66 & Normal & 84 & 124 & 74 & 74 & 68 & 1.26 \\
\hline 28 & $F$ & 52 & Normal & 87 & 135 & 125 & 99 & 81 & 1.65 \\
\hline
\end{tabular}

Table 3. Cumulative results of the glucose tolerance test. Mean values \pm Standard Error of the Mean

\begin{tabular}{|c|c|c|c|c|c|c|c|c|c|c|}
\hline \multirow[t]{2}{*}{ Group } & \multicolumn{2}{|c|}{ Sex } & \multicolumn{2}{|l|}{ Age } & \multicolumn{5}{|c|}{ Oral G.T.T. (Blood sugar values, mg per $100 \mathrm{ml}$ ) } & \multirow{2}{*}{$\begin{array}{l}\text { Intravenous } \\
\text { G.T.T. (K-Va- } \\
\text { lue })\end{array}$} \\
\hline & $\overline{\mathbf{M}}$ & $\mathbf{F}$ & Mean & Range & Fast & $1 \mathrm{~h}$ & $11 / 2 h$ & $2 \mathrm{~h}$ & $21 / 2 h$ & \\
\hline $\begin{array}{l}\text { Controls } \\
\text { Patients }\end{array}$ & $\begin{array}{l}9 \\
9\end{array}$ & $\begin{array}{l}5 \\
5\end{array}$ & $\begin{array}{l}37.7 \\
34.0\end{array}$ & $15-64$ & $\begin{array}{l}83.0 \pm 2.4 \\
90.0 \pm 2.8\end{array}$ & $\begin{array}{l}105.0=7.4 \\
139.5 \pm 9.8\end{array}$ & $\begin{array}{l}101.0 \pm 6.8 \\
128.5 \pm 12.8\end{array}$ & $\begin{array}{c}83.0 \pm 4.8 \\
110.0 \pm 10.0\end{array}$ & $\begin{array}{r}77.0 \pm 3.0 \\
102.5 \pm 7.5\end{array}$ & $\begin{array}{l}1.88 \pm 0.19 \\
1.25 \pm 0.14\end{array}$ \\
\hline
\end{tabular}

Five of them (No. 2, 3, 5,6, 10) had also shown abnormal oral G.T.T.

The mean age of patients with abnormal and normal responses was 43.1 土 6.2 and 27.2 土 5.3 years, respectively, yielding a difference statistically significant at $P=0.05$. The individual $K$-values in this group, graphically represented in Fig. 2 , ranged from 0.70 to 2.77 (mean $1.25 \pm 0.14$ ). 
G6PD acivity. All the control subjects disclosed normal enzyme aotivity, whereas the patients were all enzyme deficient. Eight of them, 6 males and 2 females, were shown to have complete absence of enzyme activity; the remainder, 3 males and 3 females, had partial enzyme deficiency.

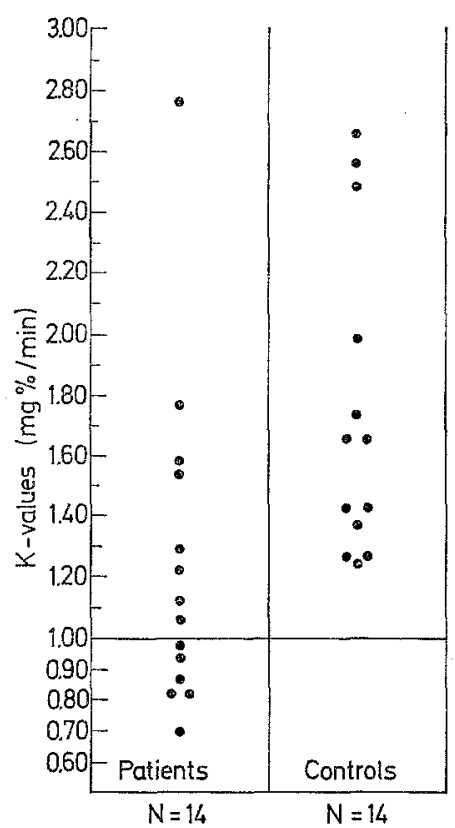

Fig. 2. Intravenous glucose tolerance tests. The distribution of $K$-values

\section{Discussion}

Favism is known to be due to a variant of G6PD. deficiency which occurs in Caucasians (Sveinberg et al. 1957, Zannos-Mariolea and Kattamis 1961). The disorder was found, in this study, to be associated with abnormal oral and/or intravenous G.T.T. in 9 out of 14 patients or 64.3 per cent. In 5 of these 9 patients, both tests were abnormal.

The results are in accord with those reported by Chanmugam and Frumin (1964), who obtained abnormal or frankly diabetic oral glucose tolerance curves in 11 of 13 G6PD-deficient adult Negroes. Although, subsequently, Eppes et al. (1966) found normal responses to oral G.T.T. in 44 G6PD-deficient Negroes, the cortisone-modified G.T.T. which they also carried out in 16 of their subjects, disclosed a decrease in glucose tolerance. It seems, therefore, that G6PD-deficiency impairs, to a variable extent, the overall carbohydrate metabolism. In support of this view is the work of Carson et al. (1963, 1966) who found, by means of ${ }^{14} \mathrm{C}$-labelled glucose and respiration analysis studies, a considerable depression of oxidative and non-oxidative utilization of glucose in G6PD-deficient subjects.

No apparent relationship was found in this study between the abnormal responses of the glucose tolerance tests and the sex of the patients, the degree of anaemia or the severity of the enzyme defect. Age, on the other hand, might have affected the results of the tests in some cases, since there was a statistically significant difference in the mean age between the patients with abnormal and those with normal, oral and intravenous, glucose tolerance tests. Increasing age has, in fact, been shown to be frequently associated with diabetic-like responses to standard oral (Hayner et al., 1965), cortisone-modified (Pozefski et al., 1965) and intravenous (Silverstone et al., 1956; Crockford et al., 1966) G.T.T. Yet age alone could hardly account for the abnormal results, because our control series consisted of subjects of comparable age with that of the patients. Our 6 older control subjects, aged 40 to 66 years, showed a mean $K$-value of 1.43 , which compares quite favourably with that reported by Silverstone et al. (1956) for a similarly aged group of normal subjects.

It is conceivable that the stress of haemolysis might cause a decrease in carbohydrate tolerance. However, such an explanation, although it may hold true for the elevated blood sugar values found on admission to the hospital, does not seem to account for the abnormal responses of the glucose tolerance tests that were done several days after the haemolytic episode had subsided.

In regard to the initial blood sugar values, two other possible sources of error should also be mentioned: haemolysis itself, which might cause an increase in non-glucose reducing substances, since the blood sugar determinations were not done by an enzymatic method; and anaemia, which might shift the blood sugar values towards those obtained in plasma. However, it seems unlikely that either factor might lead to any significant methodical error. Moreover, there is no apparent correlation between the initial blood sugar values and those of the serum bilirubin or of the haematocrit.

In view of the frequent occurrence of G6PD-deficiency in Greek individuals, estimated to be at least 0.7 per cent of the entire population (Zannos-Mariolea and Kattamis, 1961), it would be of interest to see whether the decreased carbohydrate tolerance, shown in this study, will persist in the future or result in overt diabetes. Studies now in progress might enable us to draw a more definite answer on this problem.

\section{References}

Amatuzio, D.S., Stutzman, F.L., Vanderbilt, M.J., Nesbitt, S.: Interpretation of the rapid intravenous glucose tolerance test in normal individuals and in mild diabetes mellitus. J. clin. Invest. 32, 428-435 (1953).

Carson, P.E., Frischer, M.: Glucose-6-phosphate dehydrogenase deficiency and related disorders of the pentose phosphate pathway. Amer. J. Med. 41, 744-761 (1966).

- Okita, G.T., Frischer, M., Mirasa, J., Long, W. K., Brewer, G.J.: Patterns of hemolytic susceptibility and metabolism. In: Proceedings of the 9 th Congress of European Society of Haematologists, Lisbon 1963. Basel, New York: S. Karger 1963. 
Chanmugam, D., Frumin, A.M.: Abnormal oral glucose tolerance response in erythrocyte glucose-6-phosphate dehydrogenase deficiency. New Engl. J. Med. 271, $1202-1204$ (1964)

Crockford, P.M., Harbeck, R.J., Williams, R.H.: Influence of age on intravenous glucose tolerance and serum immunoreactive insulin. Lancet 1966 I, 465467.

Duncan, L.J.P.: The intravenous glucose tolerance test. Quart. J. Physiol. 41, 85-96 (1956).

Eppes, R.B., Brewer, G.J., De Gowin, R.L., Me Namara, J.V., Flamagan, C.L., Sohrier, S.L., Tarlov, A.R., Powell, R.D., Carson, P.E.: Oral glucose tolerance in Negro men deficient in glucose-6-phosphate dehydrogenase. New Engl. J. Med. 275, 855-861 (1966).

Hayner, N.S., Kjelsberg, M.O., Epstein, F.H., Francis, T.: Carbohydrate tolerance and diabetes in a total community, Tecumseh, Michigan. Effects of age, sex and test conditions, on one-hour glucose tolerance in adults. Diabetes 14, 413-423 (1965).

Lundbaek, K.: Intravenous glucose tolerance as a tool in definition and diagnosis of diabetes mellitus. Brit. med. J. 1962 I, $1507-1513$.
Mosenthal, M. O., Barry, E.: Criteria for and interpretation of normal glucose tolerance tests. Ann. intern. Mod. 33, 1175-1194 (1950).

Motulski, A.G., Kraut, J.M., Thiems, W.T., Musto, D.F.: Biochemical genetics of glucose-6-phosphate dehydrogenase aetivity. Clin. Res. Proc. 7, 89 (1959).

Pozefski, T., Colker, J.L., Langs, H.M., Andres, R. : Cortisone-glucose tolerance test: influence of age on performance. Ann. intern. Med. 63, 988 - 997 (1965).

Silverstone, F.A., Brandfonbrener, M., Shock, N.W., Yiengst, M.J.: Age differences in the intravenous glucose tolerance tests and the response to insulin. J. clin. Invest. 36, 504-514 (1956).

Sveinberg, A., Sheba, C., Hieshorn, N., Bodonyi, E.: Studies on erythrocytes in cases with past history of favism and drug-induced acute hemolytic anomia. Blood 12, 603-613 (1957).

Zannos-Mariolea, L., Kattamis, Chr.: Glucose-6-phosphate dehydrogenase deficieney in Greece. Blood 18, $34-47$ (1961)

Anthony Billis, M.D.

$71 \mathrm{a}$, Skoura St.

Athens 144, Greece 